\title{
From jazz notes to bank notes: The determinants of spending by black music festival attendees
}

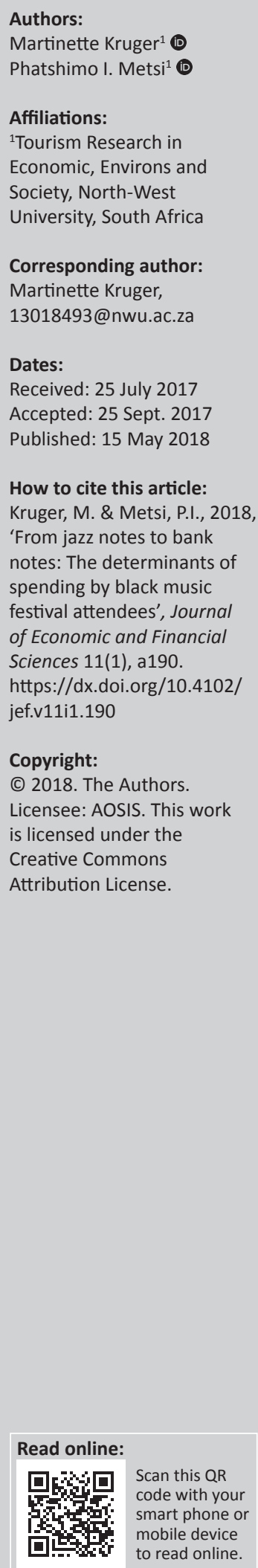

\begin{abstract}
Diamonds and Dorings Music Festival is used as a strategy to increase attendee numbers and associated spending to boost the economy of Kimberley and Northern Cape Province. The festival attracts mostly the Black Diamond market, a term coined to describe South Africa's black middle-class people. In the festival context, the Black Diamonds can be regarded as a niche and emerging market that is growing in the South African economy. Unfortunately, to date, limited research has focused on the needs and spending power of this market at music festivals. To fill this gap, this research identified the determinants of the festival attendees' spending. A visitor survey was conducted at the festival in 2015 where 367 questionnaires were administered. A linear regression analysis identified the determinants of attendee spending that included a higher number of tickets purchased, all spending components, being a local resident, staying with family and friends, staying in a guest house or B\&B and hearing about the festival on the radio. These determinants have a significant influence on respondents' behaviour to spend more money when attending the festival. Marketers and organisers of Diamonds and Dorings should focus on these determinants to influence higher spending at the festival in future.
\end{abstract}

\section{Introduction}

Events and festivals are frequently used to attract tourists to a destination (Hudson et al. 2015). According to Alves, Cerro and Martins (2010), events and festivals can be applied as a tool to preserve many attractions. The preservation of these attractions can lead to financial benefits and the distribution of artistic and cultural heritages. Also, events are seen as a significant motivator of tourism (Small 2016). Hence, they are being included in the development and marketing plans of most destinations (Getz 2008). Alves et al. (2010), Page and Connell (2014) and Saayman and Saayman (2015) add that the hosting of events holds various benefits for the hosts such as investment opportunities, local community employment, economic diversification, improved infrastructure, increased economic equity between urban and rural populations as well as destination awareness. Considering these benefits, it is not surprising that destinations all over the world host events. Developing countries such as South Africa are no exception and the country hosts a variety of events and festivals in all nine provinces.

The Northern Cape is the largest and most sparsely populated province of South Africa. The province has a variety of cultural attractions and is known for the incredible floral display in Namaqualand. Attractions that induce attendees to visit the province include the Diamond Fields, the Kalahari, the Big Hole in Kimberley and the Kgalagadi Transfrontier Park (SA-Venues.com 2015). The Northern Cape Tourism Authority states that their goal or strategy is threefold: (1) to market the Northern Cape Province; (2) attract international attendees from its key source markets to the province; and (3) inspire domestic tourists to travel through the country and the province for both leisure and business events. The aim is thus to grow the value of tourism in the Northern Cape by forming a partnership with the industry to produce inspiring marketing campaigns that position and sell the province as an anticipated destination within southern Africa to the industry and attendees (Northern Cape Tourism Authority 2015). The Northern Cape Tourism Authority already employs a strategy to facilitate and expand tourism in the Northern Cape Province by hosting various events like the Diamonds and Dorings Music Festival (hereafter referred to as 'Diamonds and Dorings').

Diamonds and Dorings celebrated its 14th year in 2015. Each year in April, the festival takes place at Langleg Resort. It is a one-day festival showcasing and promoting local artists of different genres (Shafaqna 2015). The aim of the festival is to boost the financial state of the Northern Cape 
Province and to bring together music lovers of all ages. The festival attracts mostly the Black Diamond market, a term coined to describe South Africa's black middle-class people, a recently emerged and rapidly growing market in the South African economy (Visagie 2013). According to the Institute for Strategic Marketing and TNS Research Surveys conducted in 2008 (UCT Unilever Institute 2008), Black Diamonds share the following characteristics: they are African or black skinned; have middle to high income; in professional occupations; well educated; own or are acquiring homes, cars and household goods; have aspirations and confidence in the future; and are credit worthy. In 2015, the spending power of this specific market was proved, as $80 \%$ of the more than 6800 tickets sold to Diamonds and Dorings was to residents in the Northern Cape Province, resulting in an economic impact of more than R7.8 million (TREES 2016).

To capitalise on the economic impact of the event in the Northern Cape Province, it is imperative that event organisers and marketers know who their target market is and how much the people in their target market(s) are willing to spend (Cohen, Prayag \& Moital 2014). This is of specific importance since little research to date has focused on the spending behaviour of the Black Diamond festival market in South Africa and the determinants that influence this spending. This research will, therefore, fill this gap in the current literature by identifying the main determinants of Black Diamond attendees at Diamonds and Dorings. Such an analysis identifies the socio-demographic and behavioural characteristics such as age, group size, the length of stay, trip purpose, travel mode and what drives higher spending (Kruger, Saayman \& Saayman 2012c; Mok \& Iverson 2000; Spotts \& Mahoney 1991; Svensson, Moreno \& Martín 2011). According to Tkaczynski and Rundle-Thiele (2011) understanding the determinants of spending can be very helpful to festival marketers and organisers in the growth of the economic impact of events and tourism activities. Therefore, based on the results of this research, recommendations can be made on how the festival can increase attendee spending, thereby leading to a greater economic impact of the festival on the host city and province.

\section{Literature review}

Determining the factors that influence attendee spending and determining which attendees spend most at an event or festival is vital for economic feasibility. After identifying the factors affecting visitor expenditure, policy development will be possible to strengthen the spending and maximise economic benefits of a festival (Thompson \& Schofield 2009). The festival organisers will then be able to apply those determinants when doing market segmentation to put more focus on those attendees who are willing to spend more money at the festival. This will assist in developing a modified festival program to attract the higher spending target market. Understanding the determinants of attendee spending will furthermore give the festival or event organisers a complete view of the variables that influence spending. Organisers can use the information that was gathered for various purposes, for example planning and marketing. The collected information is also essential for the sustainable growth of the event (Kruger, Viljoen \& Saayman 2015; Mok \& Iverson 2000; Saayman \& Saayman 2012; Serra, Correia \& Rodrigues 2015; Van der Merwe, Saayman \& Krugell 2013).

The benefits above show that knowing and understanding the determinants influencing visitor spending could help event organisers in using scarce resources effectively and efficiently. Saayman and Saayman (2012) and Kruger et al. (2015) state that events have a distinct set of determinants of spending and that the type and nature of an event has a significant influence on these determinants. Table 1 outlines the findings of previous research regarding the determinants of spending. The studies above collectively show that a variety of determinants may influence attendee spending. The identified determinants are both supported and contradicted in the various studies, while the influence of some is inconclusive. It is furthermore clear that the characteristics of the market as well the setting/ location/destination/event under investigation influence the determinants of spending. This emphasises the need for more research in this specific instance. Unfortunately, limited studies to date have focused on the spending behaviour of the Black Diamond festival market.

In one of the few studies performed to date (to the knowledge of the authors) that focused on the needs of the Black Diamond market for live music performance, Kruger and Saayman (2014) found the following attributes to motivate the Black Diamond market to attend a live music concert: artist affiliation and unique experience, entertainment value, nostalgia, event attractiveness and socialisation. This implies that when developing this market, event organisers should base their marketing messages on the given motives for attending a music event. While the research shed some light on the needs of this particular market, the determinants that may influence higher spending by these attendees were not determined. Limited other studies have also to date focused on the needs of this market regarding attending festivals and events - a gap in the current literature that this study attempts to fill. This research will thus provide information on the spending potential of this market to retain and expand the market, particularly in the context of festival marketing. Increased attendee spending will not only ensure the continued existence of a festival such as Diamonds and Dorings but will also create income and job opportunities for the host community's residents (Kim, Prideaux \& Chon 2010; Miller 2011; Saayman \& Saayman 2012). This, in turn, will lead to a positive host community that supports the festival on a continuous basis. This is imperative for Diamonds and Dorings and the reputation of the Northern Cape Province as a tourist and event destination. Moreover, the results of this study can assist festival marketers/organisers of not only Diamonds and Dorings but also other festivals aimed at this specific market. 
TABLE 1: Determinants of attendee spending as identified in the previous research.

\begin{tabular}{ll}
\hline $\begin{array}{l}\text { Spending } \\
\text { determinant(s) }\end{array}$ & Findings \\
\hline
\end{tabular}

\section{Socio-demographic determinants}

Age

Higher spenders were significantly younger.

Older attendees spent more compared to younger attendees.

Less than half of low spenders ( $41 \%$ ) were aged 50 years or younger, and $59 \%$ of low spenders were 50 years or older. Forty-eight percent of high spenders were under the age of 50 years, and $52 \%$ of heavy spenders were 50 years or older.

Occupation and Retired people tended to spend more only on particular expenditure income components, such as food.

Higher levels of annual income were associated with higher spending.

Low-income tourists spent less than middle- and high-income tourists. Attendees who had high-income occupations were high spenders.

Marital status High spenders were married.

Single tourists spent more than married tourists.

Home language Afrikaans-speaking attendees tended to spend more at the Wacky Wine Festival.

English-speaking attendees tended to spend more at the Samsung Rage Festival in South Africa.

Gender Female attendees tended to be higher spenders.

Males tended to spend more than females.

Level of education Respondents with a higher level of education were higher spenders.

Nationality

Place of residence/

Foreign nationalities tended to be higher spenders.

Spending increased for attendees from out of state.

Province of origin (location) plays a major role in visitor spending at arts festivals, national parks and sports events in South Africa; attendees from richer provinces, e.g. Gauteng and Western Cape, spent most.

Spectators from Western Cape spent less than spectators from other provinces.

Gauteng participants in Two Oceans Marathon spent more per person than those from Western Cape.

Gauteng participants spent more than participants from other provinces. Distance travelled to visit tourist attractions affects expenditure positively.

\section{Behavioural determinants}

Size of the travel Smaller groups spent more than large groups.

party (group size)

High spenders tended to travel in larger groups.

Travel purpose

Higher spenders' main purpose was to attend the festival.

Total expenditure was significantly higher for shoppers.

Length of stay Longer duration of stay was positively associated with higher spending.

Number of visits

Attendees who stayed longer tended to spend less.

First-time attendees were higher spenders.

Repeat attendees tended to be higher spenders

Travel expenses

Higher spenders spent more on accommodation.

The highest spending categories were accommodation, transport and beverages.

Overnight attendees spent more on transportation, food and beverages, and entertainment.

Satisfaction

Tourists who were more satisfied with sports and children's facilities, entertainment opportunities, the diversity of cultural events, the offerin of excursion and shopping opportunities tended to spend more in the destination in comparison with those who were less satisfied with those elements of the offering.

Preferred accommodation

Attendees with more elaborate catering needs and who preferred a combination of self-catering and other types of catering tended to spend more.

Cyclists using paid accommodation (e.g. hotels, B\&Bs and guesthouses) spent more.

Attendees staying in hotels tended to spend more.

Information Use of Internet as a source of information positively influences higher sources spending.

Attendees who heard about the festival from television tended to be lower spenders.

Attendees who heard about event/destination by word of mouth tended to be lower spenders.

Mok and Iverson (2000)

Kruger et al. (2012a, 2012b); Mak, Moncur and Yonamine (1977); Perez and Sampol (2000): Saayman and Saayman (2006a); Saayman, Van der Merwe and Pienaar (2008); Kastenholz (2005); Thrane (2002)

Mehmetoglu (2007)

Marrocu, Paci and Zara (2015)

Fredman (2008); Smolčić Jurdana and Soldić Frleta (2017); Lin, Mao and Song (2015)

Serra, Correia and Rodrigues (2015)

Saayman, Saayman and Joubert (2012); Botha et al. (2011)

Kim et al. (2010); Saayman and Saayman (2012)

Serra et al. (2015)

Saayman et al. (2012)

Kruger and Saayman (2016)

Saayman et al. (2012)

Kruger, Botha and Saayman (2012a)

Kim et al. (2010); Lin et al. (2015); Serra et al. (2015)

Marrocu et al. (2015); Thrane (2016)

Cannon and Ford (2002)

Saayman and Saayman (2006a; 2006b); Saayman et al. (2008); Streicher and Saayman (2009)

Kruger et al. (2012a)

Saayman and Saayman (2012)

Saayman and Saayman (2012)

Lee (2001); Long and Perdue (1990); Saayman et al. (2008); Marcussen (2011)

Mok and Iverson (2000); Saayman and Saayman (2006b); Serra et al. (2015)

Saayman et al. (2008); Spotts and Mahoney (1991); Kim et al. (2010)

Kim et al. (2010)

Craggs and Schofield (2009)

Van der Merwe and Saayman (2008); Thrane (2002); Mok and Iverson (2000); Spotts and Mahoney (1991); Mehmetoglu (2007); Downward and Lumsdon (2004); Saayman and Saayman (2006b); Serra et al. (2015); Tavares, Ivanov and Neves (2016); Van der Merwe et al. (2013)

Smolčić Jurdana and Soldić Frleta (2017)

Kim et al. (2010); Smolčić Jurdana and Soldić Frleta (2017); Kruger and Saayman (2016)

Van der Merwe and Saayman (2008); Van der Merwe et al. (2013);

Marrocu et al. (2015); Tavares et al. (2016); Kruger et al. (2012a)

Saayman and Saayman (2006b)

Kruger et al. (2012a); Thrane (2016)

Kim et al. (2010); Smolčić Jurdana and Soldić Frleta (2017)

Smolčić Jurdana and Soldić Frleta (2017)

Van der Merwe et al. (2007)

Streicher and Saayman (2009)

Marcussen (2011); Svensson et al. (2011); Alegre, Cladera and Sard (2011)

Marcussen (2011); Svensson et al. (2011)

Kruger, Viljoen and Saayman (2015)

Svensson et al. (2011) 


\section{Method of research}

This research was quantitative in nature and made use of a structured questionnaire. The next section discusses the method of research applied in the study.

\section{The questionnaire}

The questionnaire used in the survey had three sections. Section A measured the socio-demographic information of the respondents (age, occupation, income, province language, group size, spending behaviour and type of tickets purchased). Section B measured respondents' motives for attending the festival. This section measured 22 items on a five-point Likert scale of agreement ( $1=$ totally disagree; 2 = disagree; $3=$ undecided; $4=$ agree; and $5=$ totally agree). Section $\mathrm{B}$ also measured information on when respondents made a decision to attend the festival, who initiated the decision, the age of first festival attendance, where they heard about the festival and the preferred type of music genre. Sections A and B measured festival attendees' socio-demographic characteristics and motives, which had previously been tested at a variety of festivals, especially arts festivals in South Africa (see Botha \& Slabbert 2011; Kruger \& Saayman 2012; Kruger, Saayman \& Ellis 2010; Kruger, Saayman \& Ellis 2012b; Kruger, Saayman \& Saayman 2009; Saayman \& Saayman 2005; Van Zyl \& Botha 2004; Viviers, Botha \& Perl 2013). To date, various studies have also determined the motives of attendees to music festivals and performances (see Bracalente et al. 2011; Brown, Var \& Lee 2002; Dancer 2010; Kruger \& Saayman 2014; Kubacki 2008; Leenders 2010; Li, Huang \& Cai 2009; Oakes 2010; Pegg \& Patterson 2010; Pretorius, Viviers \& Botha 2014; Thrane 2002; as well as Manners, Kruger \& Saayman 2015). Many of the motivational items that were included in Section B of the questionnaire, especially about escape, socialisation and festival attributes, were adapted from the above-mentioned studies for this study context. In Section C, respondents also had to evaluate the festival on a five-point Likert scale of agreement, and 16 statements were measured. The items included in Section C of the questionnaire were based on and adapted from the works of Leenders (2010), Williams and Saayman (2011), Van Niekerk and Coetzee (2011), Botha, Viviers and Slabbert (2012) and Manners et al. (2015). Based on the findings from these studies, the aspects that were included related to hospitality, value and quality; the quality of the venue; information dissemination; marketing and sales; the quality and variety of artists included in the line-up; safety; the effectiveness of ticket sales; and the festival experience.

\section{Survey and sampling method}

The survey was carried out at the Langleg Resort on Sunday, 05 April 2015. Led by a moderator, eight fieldworkers (including the researchers) distributed the questionnaire. A stratified sampling method was applied and, to limit bias, a simple random sampling method was utilised within the stratified sample. In the case of the present research, the trained fieldworkers followed specific guidelines. Questionnaires were distributed to different non-homogeneous age groups, gender groups and ticket holders (general admission and VIP). The survey process was eased as the VIP ticket holders were separate from the general admission ticket holders. Every second attendee was asked to complete the questionnaire as all attendees were seated (in picnic style). Respondents were briefed about the purpose of the research beforehand to ensure that they participated willingly. Consistent with statistics, 6850 attendees (TREES 2016) attended the festival in 2015. Based on Krejcie and Morgan's (1970) formula, the recommended sample size is 361 . During the festival, 400 questionnaires were distributed, and 367 were completed in full and included in the analysis. A valid sample was therefore obtained during the survey.

\section{Profile of the respondents}

Respondents were mostly female (56\%) with an average age of 32 years, English speaking (55\%) and were earning $<$ R20 000 per annum (38\%). The majority of the respondents $(82 \%)$ were from the Northern Cape and travelled in an average group size of seven persons, paying for an average of four people and spending an average of three nights in Kimberly. The respondents bought four tickets on average, and the majority of those tickets (94\%) were general access tickets. The respondents were mostly local residents (53\%) and therefore did not have to make use of paid accommodation, and the festival was not their main reason for being in Kimberley (43\%). On average, the respondents spent R3033.77 per group at the festival, and the majority of the respondents were repeat attendees (70\%) who had previously attended the festival an average of four times. Some respondents (25\%) decided more than a month in advance of the festival to attend Diamonds and Dorings, and they were initiators of the attendance themselves (43\%). The respondents heard about the festival on the radio (42\%), preferred jazz music (51\%) and indicated that they would visit tourist attractions during the festival (74\%). This profile is similar to the findings by Kruger and Saayman (2014) on the Black Diamond market for live music performances in South Africa.

Two exploratory principal component factor analyses, using an oblimin rotation with Kaiser normalisation, identified, respectively, five motivational factors and three festival evaluation factors. Entertainment and socialisation was rated as the most important motive (3.83), followed by escape (3.50). Festival attractiveness and travel opportunity both obtained a mean value of 3.44, while prestige was rated as the least important motive. Regarding the festival evaluation factors, venue and technical aspects were rated the highest (3.74). This was followed by accessibility and convenience (3.56) and finally general management and affordability (3.43). In their research, Kruger and Saayman (2014) identified five motives, namely artist affiliation and unique experience, entertainment value, nostalgia, event attractiveness and socialisation, and five key management factors proved to be important for a memorable experience (general management, catering and amenities, marketing, accessibility and parking and souvenirs and auxiliary services). Compared to the findings the combination of motives and evaluation factors in this research is distinct. These factors 
were determined to explore whether the different spending segments at the festival differ based on their motives to attend Diamonds and Dorings and their evaluation of the festival. Knowledge of these differences can help to manage higher spending at the festival.

\section{Statistical analyses and results}

The data was captured in Microsoft Excel@ and analysed by using SPSS Version 23 (2016). The dependent (predicted) variable was total spending, which was calculated by adding the respondents' spending on the various components. The analysis consisted of three stages: recoding of the variables, Spearman's rank correlation coefficients (rho) and a linear regression analysis. The results are subsequently discussed.

\section{Recoding of the variables}

The dummy variables (socio-demographic, behavioural variables, motives, and evaluation of the festival) were firstly coded 1 and 0 to be included in the regression analysis as shown in Table 2. The recoding was carried out based on the preceding results. Only the variables with the highest percentages were recoded for ease of interpretation.

The variables in Table 2 were included in the regression analysis to determine which one had the greatest influence on total spending at Diamonds and Dorings. The relationship between the variables and total spending was firstly investigated by using Spearman's rho. These results are discussed in the next section.

\section{Results from Spearman's rho}

Spearman's rank-order correlation coefficient is a measure used to identify the strength and direction that is present between two variables on an ordinal scale (Privitera 2014). In this research, Spearman's rank correlation coefficient (rho) was applied to explore the relationship between the independent variables (Table 2) and the dependent variable (total spending). As per Pallant (2010), a value of 0 indicates no relationship, a value of 1.0 indicates a perfect positive correlation, and a value of -1.0 indicates a perfect negative correlation. Cohen (1988) suggests the following guidelines to interpret the values between 0 and 1: small effect, $r=0.1$; medium effect, $r=0.3$; and a large effect, $r=0.5$.

The following variables had a statistically significant relationship ( $p \leq 0.05)$ with total spending:

- Number of tickets purchased had a small, positive correlation coefficient $(\mathrm{CC}=0.173 ; p=0.002)$, indicating that an increase in the number of tickets purchased will result in higher total spending.

- Province of residence: Northern Cape had a small, negative correlation coefficient $(\mathrm{CC}=-0.227 ; p=0.001)$. This implies that local residents from Northern Cape Province have a lower total spending.

- The spending components tickets, accommodation, food, drinks, retail shopping, transport, CDs, souvenirs and parking
TABLE 2: Recoding of dummy variables used for Diamonds and Dorings.

\begin{tabular}{|c|c|}
\hline Variable(s) & Coding \\
\hline \multicolumn{2}{|l|}{ Demographic characteristics } \\
\hline Gender & Female $=1 ;$ male $=0$ \\
\hline Age & Open question \\
\hline Language & $\begin{array}{l}\text { English }=1 ; \text { other }=0 \\
\text { African }=1 ; \text { other }=0\end{array}$ \\
\hline Income & $<R 20000-R 140000=1 ;$ other $=0$ \\
\hline Province & $\begin{array}{l}\text { Northern Cape }=1 ; \text { other }=0 \\
\text { Gauteng }=1 ; \text { other }=0\end{array}$ \\
\hline Group size & Open question \\
\hline Number of people paid for & Open question \\
\hline Number of nights in the area & Open question \\
\hline Number of tickets purchased & Open question \\
\hline Type of accommodation & $\begin{array}{l}\text { Local resident }=1 ; \text { no }=0 \\
\text { Family or friends }=1 ; \text { no }=0 \\
\text { Guesthouse, bed and breakfast }=1 ; \text { no }=0 \\
\text { Hotel }=1 ; \text { other }=0\end{array}$ \\
\hline Age first exposed to music festivals & Open question \\
\hline \multicolumn{2}{|l|}{ Behavioural characteristics } \\
\hline Repeat visits & Yes $=1 ;$ no $=0$ \\
\hline Number of years previously attended & Open question \\
\hline Decision made to attend & $\begin{array}{l}\text { Spontaneous (spontaneous decision and } \\
\text { a month ago) }=1 \text {; planned (more than } \\
\text { a month ago, when it was announced) }=0\end{array}$ \\
\hline Attend again & Yes $=1 ;$ other $=0$ \\
\hline Motives to attend & Five-point Likert scale \\
\hline Heard about festival & $\begin{array}{l}1=\text { if respondent indicated they heard about } \\
\text { the festival from the medium (yes); } 0=\text { no }\end{array}$ \\
\hline Preferred music & $1=$ if respondent indicated yes and $0=$ no \\
\hline Evaluation of the festival & Five-point Likert scale \\
\hline Tourist attractions visited & Yes $=1 ;$ no $=0$ \\
\hline
\end{tabular}

all had positive correlation coefficients (ranging from low to high; $p \leq 0.05)$, linking higher spending in these categories to a higher total spending.

- Local resident (small $\mathrm{CC}=0.129 ; p=0.025$ ) and staying with family and friends (high $\mathrm{CC}=0.171 ; p=0.003$ ) (type of accommodation) had positive correlation coefficients with total spending. Local residents and respondents who stayed with family and friends (unpaid accommodation) had a higher total spending. Staying in guesthouses or $B \mathcal{E} B s$, on the other hand, had a medium, negative correlation coefficient $(\mathrm{CC}=-0.375 ; p=0.001)$, implying that respondents who made use of paid accommodation had a lower total spending.

- Interestingly, attend again had a small, negative correlation coefficient $(\mathrm{CC}=0.120 ; p=0.031)$. It appears that respondents who indicated that they would attend the festival again had a lower total spending.

- The significant media sources $(p<0.05)$, radio, Twitter, YouTube, pamphlets and posters, all had small to large, positive correlation coefficients. Respondents who heard about the festival from these sources had a higher total spending.

- Jazz/hip-hop (CC = 0.125; $p=0.02)$ and reggae $(\mathrm{CC}=0.113$; $p=0.040)$ as the preferred music genres had small, positive correlation coefficients. Respondents who indicated that they prefer these genres had a higher total spending.

- The motive escape had a small, positive correlation coefficient $(\mathrm{CC}=0.139 ; p=0.020)$ with total spending, indicating that respondents who were motivated by escape had a higher total spending. 
- The festival evaluation factors general management and affordability $(\mathrm{CC}=0.122 ; p=0.045)$ and venue and technical aspects $(\mathrm{CC}=0.140 ; p=0.024)$ had small positive correlation coefficients, specifying that attendees who were satisfied with these factors had higher total spending.

\section{Results from the linear regression analysis: Determinants of total spending}

A standard least squares regression analysis was performed to identify the determinants of visitor spending. A stepwise, backwards and forwards regression analysis was also performed, but the linear regression model had the best results. Only the statistically significant independent variables identified with Spearman's rho were included in the final model. In the regression analysis, $R^{2}$ gives the proportion of variance in spending and is explained through the predictors included in the model. An $R^{2}$ of 0.25 or larger can be considered as practically significant (Ellis \& Steyn 2003). The adjusted $R^{2}$ indicates how much variance in the outcome would be accounted for if the model had been derived from the population from which the sample was taken. It also takes into account the number of explanatory variables in the model (Field 2005). The adjusted $R^{2}$, therefore, gives an idea of how well the regression model generalises and, ideally, its value needs to be the same or very close to the value of $R^{2}$ (Field 2005). The $R$ value, which represents the simple correlation, was 1.000 , which indicated a good level of prediction. The $R^{2}$ value $(0.999)$ is the proportion of the variance in the dependent variable that can be explained by the independent variables. The adjusted $R^{2}$ had the same value (0.999). The significant variables in the model, therefore, explained $99 \%$ of the variance for total spending. The F-ratio indicated whether the overall regression model was a good fit for the data. The independent variables statistically significantly predicted the dependent variable (total spending), $F(25,93)=6258.283$, $p=0.001$. These results indicate that the model was a good fit for the data.

The statistically significant independent determinants of total spending are indicated in Table 3. The number of tickets purchased, all the spending components, local residents, staying with family and friends, staying in a guesthouse or B\&B and radio were statistically significant $(p<0.05)$. The positive signs of the beta coefficients indicate that respondents who purchased more tickets (beta $=0.006$ ), who had higher spending on tickets (beta $=0.248$ ), accommodation (beta $=0.256$ ), food (beta $=0.188$ ), drinks (beta $=0.526)$, retail shopping (beta $=0.294)$, transport $($ beta $=0.178)$, CDs $($ beta $=0.034)$, souvenirs $($ beta $=0.012)$ and parking ( beta $=0.016$ ) had a higher total spending. The positive beta coefficient signs also indicate that local residents (beta $=0.012$ ) and respondents who stayed with family or friends (beta $=0.010$ ) and in guesthouses or B\&Bs (beta $=0.008)$ tended to have a higher total spending. For radio, the positive sign in the coefficient (beta $=0.007$ ) indicates that respondents who heard about the festival from radio tended to be higher spenders.

\begin{tabular}{|c|c|c|c|c|c|c|c|}
\hline \multirow[t]{2}{*}{ Model } & \multicolumn{2}{|c|}{ Unstandardised coefficients } & \multirow{2}{*}{$\begin{array}{c}\begin{array}{c}\text { Standardised } \\
\text { coefficients }\end{array} \\
\text { Beta } \\
\end{array}$} & \multirow[t]{2}{*}{$t$} & \multirow[t]{2}{*}{ Sig. } & \multicolumn{2}{|c|}{$95 \%$ confidence interval for B } \\
\hline & B & Standard error & & & & Lower bound & Upper bound \\
\hline (Constant) & -414.808 & 128.762 & - & -3.222 & 0.002 & -670.504 & -159.112 \\
\hline Number of tickets purchased & 6.410 & 3.043 & 0.006 & 2.107 & $0.038 *$ & 0.367 & 12.452 \\
\hline Northern Cape & 6.203 & 24.902 & 0.001 & 0.249 & 0.804 & -43.248 & 55.653 \\
\hline Spending on tickets & 0.992 & 0.012 & 0.248 & 85.179 & $0.001 *$ & 0.969 & 1.016 \\
\hline Spending on accommodation & 1.001 & 0.015 & 0.256 & 68.920 & $0.001 *$ & 0.972 & 1.029 \\
\hline Spending on food & 0.992 & 0.017 & 0.188 & 56.885 & $0.001 *$ & 0.958 & 1.027 \\
\hline Spending on drinks & 0.999 & 0.006 & 0.526 & 179.502 & $0.001 *$ & 0.988 & 1.010 \\
\hline Spending on retail shopping & 1.004 & 0.010 & 0.294 & 97.680 & $0.001 *$ & 0.984 & 1.024 \\
\hline Spending on transport & 0.969 & 0.020 & 0.178 & 48.367 & $0.001 *$ & 0.929 & 1.009 \\
\hline Spending on CDs (compact discs) & 1.435 & 0.142 & 0.034 & 10.102 & $0.001 *$ & 1.153 & 1.718 \\
\hline Spending on souvenirs & 0.725 & 0.208 & 0.012 & 3.484 & $0.001 *$ & 0.312 & 1.138 \\
\hline Spending on parking & 1.631 & 0.316 & 0.016 & 5.169 & $0.001 *$ & 1.004 & 2.258 \\
\hline Local residents & 77.755 & 29.682 & 0.012 & 2.620 & $0.010 *$ & 18.812 & 136.699 \\
\hline Staying with family or friends & 73.684 & 28.760 & 0.010 & 2.562 & $0.012 *$ & 16.573 & 130.795 \\
\hline Staying in a guesthouse or Bed \&Breakfast & 65.558 & 32.166 & 0.008 & 2.038 & $0.044 *$ & 1.683 & 129.433 \\
\hline Attend again & 13.635 & 21.954 & 0.002 & 0.621 & 0.536 & -29.962 & 57.233 \\
\hline Radio & 40.644 & 19.085 & 0.007 & 2.130 & $0.036 *$ & 2.746 & 78.542 \\
\hline Twitter & 10.987 & 35.725 & 0.001 & 0.308 & 0.759 & -59.956 & 81.931 \\
\hline YouTube & -53.018 & 41.570 & -0.005 & -1.275 & 0.205 & -135.567 & 29.531 \\
\hline Pamphlets & 37.663 & 22.250 & 0.005 & 1.693 & 0.094 & -6.522 & 81.848 \\
\hline Posters & 7.797 & 20.995 & 0.001 & 0.371 & 0.711 & -33.894 & 49.489 \\
\hline Jazz/hip-hop & 4.435 & 18.842 & 0.001 & 0.235 & 0.814 & -32.982 & 41.851 \\
\hline Reggae & -15.289 & 20.036 & -0.002 & -0.763 & 0.447 & -55.075 & 24.498 \\
\hline Escape & -2.017 & 8.582 & -0.001 & -0.235 & 0.815 & -19.058 & 15.024 \\
\hline General management and affordability & -5.132 & 12.858 & -0.002 & -0.399 & 0.691 & -30.666 & 20.402 \\
\hline Venue and technical aspects & 12.365 & 13.339 & 0.004 & 0.927 & 0.356 & -14.123 & 38.852 \\
\hline
\end{tabular}

$\mathrm{CD}$, compact disk; $\mathrm{B} \& \mathrm{~B}$, Bed \& Breakfast.

$*$, Statistically significant, $p<0.05$ 


\section{Findings and implications}

The research has the following findings and implications. The results confirm Craggs and Schofield's (2009) notion that a variety of socio-demographic and behavioural variables influence spending. However, based on the results, more socio-economic and behavioural determinants influenced higher total spending at Diamonds and Dorings compared to demographic variables. The results further confirm that there is no universal set of spending determinants for festival attendees. The results moreover confirm the notion by Saayman and Saayman (2012) and Kruger et al. (2015) that events have a distinct set of determinants of spending and that the type and nature of an event has a significant influence on these determinants. Festival attendees, therefore, cannot be regarded as homogeneous regarding their spending behaviour and the determinants that influence this spending. Hence there is a need to research festivals independently. The influence of purchasing more tickets on higher spending has not been confirmed in previous studies. The results obtained for the spending categories confirm the findings of Saayman and Saayman (2006a; 2006b), Kruger et al. (2012a), Thrane (2016), Kim et al. (2010) and Smolčić Jurdana and Soldić Frleta (2016) that higher spending in these categories results in higher total spending.

Streicher and Saayman (2009), Marcussen (2011), Svensson et al. (2011) and Alegre et al. (2011) also found that attendees who made use of paid accommodation (guesthouses, B\&Bs and hotels) tended to be higher spenders. Conversely, the results further indicated that local residents and respondents who stayed with family and friends (unpaid accommodation) were also higher spenders. These results contradict the finding of most previous studies (see Cannon \& Ford 2002; Kruger et al. 2012a; Lee 2001; Long \& Perdue 1990; Saayman \& Saayman 2012; Saayman \& Saayman 2015 Saayman et al. 2008; Botha et al. 2011; Streicher \& Saayman 2009; Marcussen 2011) that attendees who travel further from other provinces or states tend to be higher spenders. Although the influence of radio on higher spending has not previously been confirmed, the positive result of this mass medium differs from Marcussen (2011) and Svensson et al. (2011), who found that the use of the Internet positively influences higher spending. Further contradiction emerged with research of Svensson et al. (2011), who revealed word of mouth has a negative influence on spending, and the results of Kruger et al. (2015) implicating the negative influence of television on spending.

The following recommendations are made to increase attendee spending at Diamonds and Dorings:

- The results revealed that residents of the Northern Cape were higher spenders. However, this could be since the majority of the current attendees are local residents. Therefore, marketers should continue to encourage and retain local residents from the Northern Cape Province to attend the festival, as this is their main market. Nonetheless, more should be done to attract attendees from surrounding provinces, as these attendees have the potential to be higher spenders, as they need to travel further and make use of paid accommodation. It is important to expand the festival's current target market, especially if the organisers want to effectively use the festival as an attraction to the area.

- The results further confirmed that staying in paid accommodation such as guest houses and B\&Bs lead to higher spending. It is, therefore, vital that the various accommodation offerings available in Kimberley be intensively marketed. Festival organisers should opt to introduce all-inclusive festival packages that include accommodation along with access to the festival. The festival organisation committee should form a partnership with all the tourism and hospitality businesses in Kimberley. The area should come to an agreement and gain support for the packages above. This can be a way to encourage more attendees to travel further from surrounding areas and provinces. Moreover, it will provide much-needed support to the local hospitality industry.

- Respondents who were motivated by escape had a higher total spending. This result implies that organisers and marketers should emphasise their marketing campaigns to highlight that attending the festival is the ideal opportunity to escape from daily tension. Since the festival is usually held over Easter weekend, the festival should use this to their advantage to further highlight this motive. Another public holiday (Family Day) follows the festival and therefore creates another opportunity to attract more attendees from surrounding areas and provinces. Therefore, the motive escape should form an essential part of the festival marketing.

- Based on Spearman's rho, respondents who were satisfied with the venue and technical aspects had a higher total spending; this means that higher spenders are satisfied with the festival venue (Langleg Resort). Although technical aspects are also important, it is imperative that the organisers ensure that the quality of the sound and lighting at the venue is excellent. Outdoor venues always present certain challenges in this regard. However, organisers should keep in mind that these factors could also create a memorable experience and increase attendee numbers and spending.

- Spearman's rho showed that attendees who rated general management and affordability as important had a higher total expenditure; this means that festival attendees who are satisfied with the manner in which the festival was managed and who are satisfied with the prices will demonstrate higher spending behaviour. It is thus essential that a high quality attendee experience is given. It is also necessary for management not to overprice the tickets, food and drinks to ensure festival affordability.

- Higher spending on the spending components were significant variables (determinants) influencing higher spending. These include spending on tickets, food and drinks, retail and transport. The following are recommendations that organisers should consider to increase attendee spending in the categories. Tickets should 
firstly be affordable. The majority of respondents purchased general access tickets. Although affordability was an important festival evaluation aspect, attendees need to feel they receive value for their money. Here the line-up and combination of performing artists can play a significant role. Since attendees are allowed to bring their own food and drinks to the festival grounds, organisers should revise this strategy. Rather, attendees should be encouraged to spend more at the festival and support the various vendors. However, this will also imply a greater variety of food and drinks on offer at affordable prices. Local vendors and entrepreneurs should be encouraged to form part of the festival as they can benefit financially from attendee spending. This will also ensure long-term support for the festival.

- Spearman's rho further confirmed that Twitter, YouTube, pamphlets and posters had an influence on higher spending while the results of the regression analysis singled out radio as the marketing medium influencing higher spending. Festival marketers should, therefore, use these media platforms extensively to market the festival and to engage attendees actively. Marketing campaigns should be amusing and exciting, and they should catch the attention of the target audience. Based on the findings, the following marketing ideas are suggested:

- As radio campaigns play a significant role in encouraging higher spending, the festival should be marketed on the local Kimberley radio stations (a full list of stations can be obtained from http:// streema.com/radios/Kimberley). However, marketing campaigns should be expanded to national radio stations such as Ukhozi FM and Metro FM as these stations currently have the most listeners weekly (Writer 2016). Expanding campaigns to national radio stations could also be a way to reach more attendees from surrounding provinces, that is, more potential high spenders.

- Spearman's rho indicated that YouTube positively influences higher spending. It is, therefore, important that the festival create marketing videos about the festival showing the line-up and past festival experiences. These videos should be posted after the previous year's festival, while short promotional videos can be created to be published in the weeks leading up to the festival to tantalise attendees' curiosity. Links to the videos can be posted on Twitter to promote the festival further. Promotional videos can also be an effective way to incorporate the identified motives by showing the festival experience.

- Along with the date and venue, the line-up of artists should be the main feature on pamphlets and posters. Distributing pamphlets before the festival could also be a way to create employment for the local residents of Kimberley.

- The music genres jazz/hip-hop and reggae had positive influences on higher spending according to Spearman's rho. Although not significant, however, the regression analysis indicated that reggae had a negative influence on higher spending. A possible explanation for this could be that attendees currently do not have a keen preference for this genre of music. Festival organisers should, therefore, ensure that a combination of jazz/hip-hop artists is included in the line-up, as this will encourage attendees to spend more money to attend the festival. A small number of reggae artists can also be included in the line-up, as this will give a greater variety to the programme. However, if this aspect is included in the line-up, it should be marketed, and the artists should be based on the needs of the market.

\section{Conclusion}

This research identified the determinants of attendee spending at Diamonds and Dorings. It is evident from the results that a variety of determinants influence the spending of attendees at Diamonds and Dorings. Previous research findings both support and contradict these determinants and emphasise that the type and nature of the festival affect the combination of influential determinants. This research made a significant contribution to the current literature on festival attendees in South Africa. For the first time, the profile and spending behaviour of the Black Diamond music market were analysed. The results showed that this niche market has significant spending power. Based on the results, recommendations were made regarding marketing and management on how to increase attendees' spending at Diamonds and Dorings. The latter is not only important to the marketers and organisers of the festival, but also to other similar festivals in the country aimed at attracting this lucrative market. More research should be carried out on the Black Diamond market at other music festivals and events to gain comprehensive insights into the needs and spending behaviour of this niche market. From the results, it is evident that there is no universal set of determinants that distinguish higher spenders at festivals and events. Ongoing research is, therefore, essential as it can help spread the hosting of music festivals geographically in all nine South African provinces.

\section{Research limitations}

One of the most important aspects evident from the spending analysis is respondents' failure to indicate for how many people they paid. For this reason, spending per person could not be calculated. The results showed that on average, respondents travelled in a group size of seven people and were financially responsible for four of those people. Unfortunately, only 36 respondents (10\%) indicated the number of people they were paying for, making calculations based on spending per person impossible. Ideally, spending per person should be used since festival organisers want to influence individual spending at the festival. Although the total spending analyses provided useful information on how to increase attendee spending at the festival, respondents nevertheless, should be encouraged to complete all sections of the questionnaire and fieldworkers need to explain the importance of completing questionnaires accurately. Future researchers should, therefore, pay attention to this important aspect. 


\section{Acknowledgements}

The authors gratefully acknowledge the financial assistance from the National Research Foundation (NRF). They are also grateful to the event organisers, all the fieldworkers and willing respondents.

\section{Competing interests}

The authors declare that they have no financial or personal relationships which may have inappropriately influenced them in writing this article.

\section{Authors' contributions}

Both authors equally contributed to the research and writing of this article.

\section{References}

Alegre, J., Cladera, M. \& Sard, M., 2011, 'Analysing the influence of tourist motivations on tourist expenditure at a sun-and-sand destination', Tourism Economics 17(4), 813-832. https://doi.org/10.5367/te.2011.0063

Baptista Alves, H.M., María Campón Cerro, A. \& Vanessa Ferreira Martins, A., 2010 'Impacts of small tourism events on rural places', Journal of Place Management and Development 3(1), 22-37. https://doi.org/10.1108/17538331011030257

Botha, K. \& Slabbert, E., 2011, 'Market segmentation of visitors to Aardklop National Arts Festival: A correspondence analysis', Management Dynamics: Journal of the Southern African Institute for Management Scientists 20(1), 2-18.

Botha, K., Slabbert, E., Rossouw, R. \& Viviers, P.A., 2011, 'Expenditure-based segmentation of visitors to Aardklop National Arts Festival', South African Theatre Journal 25(2), 142-166. https://doi.org/10.1080/10137548.2011.639168

Botha, K., Viviers, P.A. \& Slabbert, E., 2012, 'What really matters to the audience: Analysing the key factors contributing to arts festival ticket purchases', South African Theatre Journal 26(1), 22-44. https://doi.org/10.1080/10137548.2 012.754080

Bracalente, B., Chirieleison, C., Cossignani, M., Ferrucci, L., Gigliotti, M. \& Ranalli, M.G. 2011, 'The economic impact of cultural events: The Umbria Jazz music festival', Tourism Economics 17(6), 1235-1255. https://doi.org/10.5367/te.2011.0096

Brown, M.D., Var, T. \& Lee, S., 2002, 'Messina Hof Wine and Jazz Festival: An economic impact analysis', Tourism Economics 8(3), 273-279. https://doi.org/10.5367/ 000000002101298115

Cannon, T.F. \& Ford, J., 2002, 'Relationship of demographic and trip characteristics to visitor spending: An analysis of sport travel visitors across time', Tourism Economics 8(3), 263-271. https://doi.org/10.5367/000000002101298106

Cohen, J., 1988, Statistical power analysis for the social sciences, Erlbaum, Hillsdale, MI.

Cohen, S.A., Prayag, G. \& Moital, M., 2014, 'Consumer behaviour in tourism: Concepts, influences and opportunities', Current Issues in Tourism 17(10), 872-909. https:// doi.org/10.1080/13683500.2013.850064

Craggs, R. \& Schofield, P., 2009, 'Expenditure-based segmentation and visitor profiling at The Quays in Salford, UK', Tourism Economics 15(1), 243-260. https://doi. org/10.5367/000000009787536753

Dancer, T., 2010, 'Jazz festivals and intangible heritage. South African Jazz Heritage at the Standard Bank Joy of Jazz Festival in Newtown', Unpublished Masters dissertation, University of the Witwatersrand, Johannesburg.

Downward, P. \& Lumsdon, L., 2004, 'Tourism transport and visitor spending: A study in The North York Moors National Park, UK', Journal of Travel Research 42(4), 415-420. https://doi.org/10.1177/0047287504263038

Ellis, S.M. \& Steyn, H.S., 2003, 'Practical significance (effect sizes) versus or in combination with statistical significance ( $p$-values): Research note. Management dynamics', Journal of the Southern African Institute for Management Scientists 12(4), 51-53.

Field, A., 2005, Discovering statistics using SPSS, 2nd edn., Sage, London.

Fredman, P., 2008, 'Determinants of visitor expenditures in mountain tourism' Tourism Economics 14(2), 297-311. https://doi.org/10.5367/0000000087844 60418

Getz, D., 2008, 'Event tourism: Definition, evolution, and research', Tourism Management 29(3), 403-428. https://doi.org/10.1016/j.tourman.2007.07.017

Hudson, S., Roth, M.S., Madden, T.J. \& Hudson, R., 2015, 'The effects of social media on emotions, brand relationship quality, and word of mouth: An empirical study of music festival attendees', Tourism Management 47(1), 68-76. https://doi. org/10.1016/j.tourman.2014.09.001

Kastenholz, E., 2005, 'Analysing determinants of visitor spending for the rural tourist market in North Portugal', Tourism Economics 11(4), 555-569. https://doi.org/ 10.5367/000000005775108728
Kim, S.S., Prideaux, B. \& Chon, K., 2010, 'A comparison of results of three statistical methods to understand the determinants of festival participants' expenditures', International Journal of Hospitality Management 29(2), 297-307. https://doi.' org/10.1016/j.ijhm.2009.10.005

Krejcie, R.V. \& Morgan, D.W., 1970, 'Determining the sample size for research activities, educational and psychological measurement', Educational and Psychological Measurement 30(3), 607-610. https://doi.org/10.1177/00131 6447003000308

Kruger, M., Botha, K. \& Saayman, M., 2012a, 'The relationship between visitor spending and repeat visits: An analysis of spectators at the Old Mutual Two Oceans Marathon', Acta Commercii 12(1), 108-122. https://doi.org/10.4102/ ac.v12i1.139

Kruger, M. \& Saayman, M., 2012, 'When do festinos decide to attend an arts festival? An analysis of the Innibos National Arts Festival', Journal of Travel and Tourism Marketing 29(2), 147-162. https://doi.org/10.1080/10548408.2012.648538

Kruger, M. \& Saayman, M., 2014, 'Exploring South Africa's "black diamonds" at live music performances', Acta Commercii 14(1), 1-13. https://doi.org/10.4102/ac. v14i1.222

Kruger, M. \& Saayman, M., 2016, 'Expenditure-based segmentation: A case analysis of attendees to a youth festival in South Africa', Tourism Review International 20(23), 91-101. https://doi.org/10.3727/154427216X14713104855856

Kruger, M., Saayman, M. \& Ellis, S., 2012b, 'Determinants of visitor spending, an evaluation of participants and spectators at the Two Oceans Marathon', Tourism Economics 18(6), 1203-1227. https://doi.org/10.5367/te.2012.0174

Kruger, M., Saayman, M. \& Ellis, S.M., 2010, 'Does loyalty pay? First-time versus repeat visitors at a national arts festival', Southern African Business Review 14(1), 79-104.

Kruger, M., Saayman, M. \& Saayman, A., 2009, 'Expenditure-based segmentation of visitors to the Klein Karoo National Arts Festival', in R.S. Rensburg, et al. (eds.) Conference proceedings of the 20th annual conference and the 21st birthday of
the Southern African Institute for Management Scientists. Misty Hills Hotel conference Centre and Spa in the Country, Muldersdrift, September14-17, 2008 conference Centr
pp. 248-270.

Kruger, M., Saayman, M. \& Saayman, A., 2012c, 'Identifying the big spenders at a national arts festival', Acta Academica 44(3), 74-94.

Kruger, M., Viljoen, A. \& Saayman, M., 2015, 'Who are the big spenders at a motorcycle event?', Journal of Economic and Financial Sciences 8(2), 327-353.

Kubacki, K., 2008, 'Jazz musicians, creating service experience in live performance', International Journal of Contemporary Hospitality Management 20(4), 303-313. https://doi.org/10.1108/09596110810873516

Lee, H., 2001, 'Determinants of recreational boater expenditures on trips', Tourism Management 22(6), 659-667. https://doi.org/10.1016/S0261-5177(01)00033-4

Leenders, M.A., 2010, 'The relative importance of the brand of music festivals, a customer equity perspective', Journal of Strategic Marketing 18(4), 291-301. https://doi.org/10.1080/09652541003768061

Li, M., Huang, Z. \& Cai, L.A., 2009, 'Benefit segmentation of visitors to a rural community-based festival', Journal of Travel and Tourism Marketing 26(5-6), 585-598. https://doi.org/10.1080/10548400903163152

Lin, V.S., Mao, R. \& Song, H., 2015, 'Tourism expenditure patterns in China', Annals of Tourism Research 54(1), 100-117. https://doi.org/10.1016/j.annals.2015.07.001

Long, P.T. \& Perdue, R.R., 1990, 'The economic impact of rural festivals and special events: Assessing the spatial distribution of expenditures', Journal of Travel Research 28(4), 10-14. https://doi.org/10.1177/004728759002800403

Mak, J., Moncur, J. \& Yonamine, D., 1977, 'Determinants of visitors expenditures and visitor lengths of stay: A cross-section analysis of U.S. visitors to Hawaii', Journal of Travel Research 15(3), 5-8. https://doi.org/10.1177/004728757701500302

Manners, B., Kruger, M. \& Saayman, M., 2015, 'Different venues, different markets, different experiences: Evidence from live music performances in South Africa', South African Journal for Research in Sport, Physical Education and Recreation 37(2), 61-82.

Marcussen, C.H., 2011, 'Determinants of tourist spending in cross-sectional studies and at Danish destinations', Tourism Economics 17(4), 833-855. https://doi. org/10.5367/te.2011.0068

Marrocu, E., Paci, R. \& Zara, A., 2015, 'Micro-economic determinants of tourist expenditure, a quantile regression approach', Tourism Management 50(1), 13-30. https://doi.org/10.1016/j.tourman.2015.01.006

Mehmetoglu, M., 2007, 'Nature-based tourists, the relationship between their trip expenditures and activities', Journal of Sustainable Tourism 15(2), 200-215. https://doi.org/10.2167/jost642.0

Miller, R.L., 2011, 'The role of the saxophone embouchure in the production of the South African jazz sound: A study of nine jazz saxophone players', Unpublished PhD thesis, University of Cape Town, Cape Town.

Mok, C. \& Iverson, T.J., 2000, 'Expenditure-based segmentation: Taiwanese tourists to Guam', Tourism Management 21(3), 299-305. https://doi.org/10.1016/S0261 5177(99)00060-6

Northern Cape Tourism Authority, 2015, What is the Northern Cape Tourism Authority? viewed 12 May 2015, from http://experiencenortherncape.com/ corporate/about-us/

Oakes, S., 2010, 'Profiling the jazz festival audience', International Journal of Event and Festival Management 1(2), 110-119. https://doi.org/10.1108/17852951011 056892

Page, S. \& Connell, J., 2014, The Routledge handbook of events, Routledge, New York. Pallant, J., 2010, SPSS survival manual, 3rd edn., McGraw-Hill, New York. 
Pegg, S. \& Patterson, I., 2010, 'Rethinking music festivals as a staged event, gaining insights from understanding visitor motivations and the experiences they seek',
Journal of Convention and Event Tourism 11(2), 85-99. https://doi.org/10.1080/ Journal of Convention

Perez, E.A. \& Sampol, J.C., 2000, 'Tourist expenditure for mass tourism markets', Annals of Tourism Research 27(3), 624-637. https://doi.org/10.1016/S01607383(99)00101-2

Pretorius, S.C., Viviers, P. \& Botha, K., 2014, 'Is it still about the arts? The perceived contribution of KKNK to the arts', South African Theatre Journal 27(3), 159-182. https://doi.org/10.1080/10137548.2014.910964

Privitera, G.J., 2014, Statistics for the behavioural sciences, 2nd edn., Sage, New York.

Saayman, A. \& Saayman, M., 2005, 'Socio-demographics and visiting patterns of arts festivals in South Africa', Event Management 9(4), 211-222. https://doi.org/ 10.3727/152599506776771553

Saayman, M. \& Saayman, A., 2006a, 'Does the location of arts festivals matter for the economic impact?', Papers in Regional Science 85(4), 569-584. https://doi. org/10.1111/j.1435-5957.2006.00094.x

Saayman, M. \& Saayman, A., 2006b, 'Estimating the economic contribution of visitor spending in the Kruger National Park to the regional economy', Journal of Sustainable Tourism 14(1), 67-81. https://doi.org/10.1080/09669580608668592

Saayman, M. \& Saayman, A., 2012, 'Determinants of spending, an evaluation of three major sporting events', International Journal of Tourism Research 14(2), 124-138. https://doi.org/10.1002/jtr.841

Saayman, M. \& Saayman, A., 2015, 'Economic impact of cultural events', South African Journal of Economic and Management Sciences 7(4), 629-642. https://doi. org/10.4102/sajems.v7i4.1294

Saayman, M., Saayman, A. \& Joubert, E.M., 2012, 'Expenditure-based segmentation of visitors to the Wacky Wine Festival', Tourism Recreation Research 37(3), 215-225. https://doi.org/10.1080/02508281.2012.11081710

Saayman, M., Van Der Merwe, P. \& Pienaar, J., 2008, 'Expenditure-based segmentation of South African biltong hunters', Acta Academica 41(3), 107-127.

SA-Venues, 2015, Kimberley and Northern Cape, Northern Cape Attractions, viewed 13 May 2015, from http://www.sa-venues.com/north_cape_attractions_info.htm.

Serra, J., Correia, A. \& Rodrigues, P.M., 2015, 'Tourist spending dynamics in the Algarve: A cross-sectional analysis', Tourism Economics 21(3), 475-500. https:// doi.org/10.5367/te.2015.0482

Shafaqna, 2015, Diamonds and Dorings Festival set to draw crowds, viewed 12 May 2015, from http://southafrica.shafaqna.com/EN/ZA/14625.

Small, K.E., 2016, 'Understanding the social impacts of festivals on communities', Unpublished PhD thesis, University of Western Sydney, Sydney.

Smolčić Jurdana, D. \& Soldić Frleta, D., 2017, 'Satisfaction as a determinant of tourist expenditure', Current Issues in Tourism 20(7), 691-704.

Spotts, D.M. \& Mahoney, E.M., 1991, 'Segmenting visitors to a destination region based on the volume of their expenditures', Business Research Division 29(4) based on the volume of their expenditures', Business
$42-31$. https://doi.org/10.1177/004728759102900405

SPSS, 2016, Statistical package for the social science, Version 23 (Computer Software), IBM, Chicago, IL.

Streicher, H. \& Saayman, M., 2009, 'The determinants of spending of participants in the Cape Argus Cycle Tour', Journal for Sport, Physical Education and Recreation 32(1), 121-131.
Svensson, B., Moreno, P. \& Martín, D., 2011, 'Understanding travel expenditure by means of market segmentation', The Service Industries Journal 31(10), 1683-1698. https://doi.org/10.1080/02642069.2010.503891

Tavares, J.M., Ivanov, S. \& Neves, O.F., 2016, 'Determinant of tourists' spending during tours: The case of repeat vs. first-time visitors to State Minas Gerais, Brazil', Tourism Planning and Development 13(1), 23-36. https://doi.org/10.1080/21568 316.2015.1074094

Thompson, K. \& Schofield, P., 2009, 'Segmenting and profiling visitors to the Ulaanbaatar Naadam Festival by motivation', Event Management 13(1), 1-15. https://doi.org/10.3727/152599509789130601

Thrane, C., 2002, 'Jazz festival visitors and their expenditures: Linking spending patterns to musical interest', Journal of Travel Research 40(3), 281-286. https:// doi.org/10.1177/0047287502040003006

Thrane, C., 2016, 'The determinants of Norwegians' summer tourism expenditure, foreign and domestic trips', Tourism Economics 22(1), 31-46. https://doi.org/ 10.5367/te.2014.0417

Tkaczynski, A. \& Rundle-Thiele, S.R., 2011, 'Event segmentation, A review and research agenda', Tourism Management 32(2), 426-434. https://doi.org/10.1016/ j.tourman.2010.03.010

TREES, 2016, An analysis of the Diamonds and Dorings Festival 2015 attendees, local business owners and community, TREES Report, North-West University, Unpublished.

UCT Unilever Institute, 2008, Black Diamonds still shine, despite gloomy economy, viewed 20 February 2016, from http://www.sagoodnews.co.za/index2.php?option= com_content\&do_pdf=1\&id=1924.

Van Der Merwe, P. \& Saayman, M., 2008, 'Travel motivations of tourists visiting Kruger National Park', Koedoe 50(1), 154-159. https://doi.org/10.4102/koedoe. v50i1.140

Van der Merwe, P., Saayman, M. \& Krugell, W., 2013, 'The determinants of spending by biltong hunters', South African Journal of Economic and Management Sciences 10(2), 184-194. https://doi.org/10.4102/sajems.v10i2.578

Van Niekerk, M. \& Coetzee, W.J.L., 2011, 'Utilising the VICE model for the sustainable development of the Innibos Arts Festival', Journal of Hospitality Marketing and Management 20(3-4), 347-365. https://doi.org/10.1080/19368623.2011. 562422

Van Zyl, C. \& Botha, C., 2004, 'Motivational factors of local residents to attend the Aardklop National Arts Festival', Event Management 8(4), 213-222. https://doi. org/10.3727/1525995031436818

Visagie, J., 2013, Who are the middle class in South Africa? Does it matter for policy? In A Web Forum for Accessible Policy-Relevant Research and Expert Commentaries on Unemployment and Employment, Income Distribution and Inclusive Growth in South Africa, viewed 20 February 2016, from http://www.econ3×3.org/article/ who-are-middle-class-south-africa-does-it-matter-policy

Viviers, P.A., Botha, K. \& Perl, C., 2013, 'Push and pull factors of three Afrikaans Arts Festivals in South Africa', South African Journal for Research in Sport, Physical Education and Recreation 35(2), 211-229.

Williams, K. \& Saayman, M., 2011, 'Lessons in managing visitors' experience at the Cape Town international jazz festival', Acta Academica 43(4), 61-80.

Writer, S., 2016, These are the 10 biggest radio stations in South Africa, viewed 07 November 2016, from http://businesstech.co.za/news/media/123473/these-arethe-10-biggest-radio-stationsin-south-africa/ 